\title{
Science Sublime: The Philosophy of the Sublime, Dewey's Aesthetics, and Science EDUCATION $^{1}$
}

\section{Shane Cavanaugh}

\section{ABSTRACT}

Feelings of awe, wonder, and appreciation have been largely ignored in the working lives of scientists and, in turn, science education has not accurately portrayed science to students. In an effort to bring the affective qualities of science into the classroom, this work draws on the writings of the sublime by Burke, Kant, Emerson, and Wordsworth as well as Dewey's notion of aesthetic experiences to explore a new construct I have called the "scientific sublime." Also described is a pedagogical approach developed to teach for the scientific sublime as well as the results of utilizing this approach.

Due to the historic separation of cognition and emotion, the affective aspects of learning are often seen as trivial in comparison to the more 'essential' cognitive qualities-particularly in science. We are taught that science should objectively scrutinize the world in search of answers, and science educators have been taught to look to scientists to guide their teaching of content and processes. ${ }^{2}$ As a result, science pedagogy characteristically instructs students to step back from objects and events in order to dispassionately observe and analyze them. In an attempt to guide students towards thinking like scientists, the process of scientific inquiry is typically the focus in science. What is left out, of course, is emotion.

A surprisingly large literature exists on the role emotion, creativity, and beauty play in the working lives of scientists. ${ }^{3}$ Unfortunately, affect and aesthetics have been largely overlooked in science education. Recently, however, using Dewey's notion of aesthetic experiences, some educational researchers have sought to include affect and aesthetics in science education by developing and testing theories of aesthetic scientific learning. ${ }^{4}$ In a continued effort to bring the affective qualities of science into the classroom, this work draws on the philosophical writings of a particular branch of aesthetics, the sublime, to explore a new construct I call the "scientific sublime."

The sublime has been seen alternatively as a part of, and in contrast to, the beautiful, but always associated with feelings of awe and exceptionality. It has 
captivated poets and philosophers for hundreds of years and as will be explained, scientists as well. Writings by many scientists suggest that they in fact not only experience the sublime but also value it as part of their process of understanding. With examples from science, and through exploration of the various characterizations of the sublime, this article explores an approach developed for teaching intended to foster such sublime experiences in the science classroom.

\section{Aesthetics, Affect, And Science}

Aesthetics is typically thought of as a branch of philosophy related to beauty, particularly in the arts. However, Root-Bernstein \& Root-Bernstein offer a different description of aesthetics: "It is the integration of thinking and feeling that characterizes the highest forms of aesthetic experience in both science and arts." ${ }^{\text {In }}$ this description, Robert Root-Bernstein, a physiologist who studies connections between science and art, emphasizes the importance of emotion in aesthetics. But he also pairs the emotional with the cognitive, stating that aesthetic experiences are a combination of "thinking and feeling" and he explicitly mentions science as being capable of inducing such experiences. It is this version of aesthetics, a combination of the cognitive and affective, that can be particularly useful in thinking about science education

This work explores a particular branch of aesthetics, the sublime, for two reasons: 1) It is often used to describe strong emotions inspired by nature, consequently, it is well-suited to science; 2) It represents the ultimate in emotions, what Burke called, "the strongest passions." $\mathrm{Philosophers} \mathrm{and} \mathrm{poets} \mathrm{have} \mathrm{taken} \mathrm{a} \mathrm{variety}$ of stances on the sublime, but out of these writings two very different types emerge, what I call the extreme and the connective sublime.

\section{The Extreme Sublime}

The first type of sublime, the extreme, is best described in the writings of the two philosophers, Edmund Burke ${ }^{7}$ and Immanuel Kant. ${ }^{8}$ Both expressed feelings of reverence towards the power of nature in events like hurricanes or in the vastness of space. To contrast the sublime with the beautiful, Kant wrote, "Tall oaks and lonely shadows in a sacred grove are sublime,--flower beds, low hedges and trees trimmed in figures are beautiful. Night is sublime, day is beautiful. . . The sublime moves, the beautiful charms." Kant valued the sublime over the beautiful, portraying the beautiful as trivial while the sublime as stirring:

For just as we charge with want of taste the man who is indifferent when passing judgment upon an object of nature that we regard as beautiful; so we say of him who remains unmoved in the presence of that which we judge to be sublime, he has no feeling. ${ }^{10}$ 
While Kant considered beauty a matter of "taste," the sublime is attributed with a deeper, emotional presence. Notice the sentiments associated with Kant's sublime in contrast with those that come with beauty. We can "regard" and be charmed by something beautiful, but we are moved by the sublime. Those who do not recognize beauty have no "taste," but those not affected by the sublime have "no feeling."

Kant's sublime, as portrayed in "Observations on the Feeling of the Beautiful and Sublime" 11 and Critique of Judgment, ${ }^{1}$ is squarely that of the extreme. In Kant's works the extreme sublime is evoked by the huge, by dizzying heights, and terrifying depths, always including a sense of fear mingled with captivation. He writes of the sublime as like "the description of a raging storm ... arouse[ing] enjoyment but with horror."13 With this type of sublime we are overwhelmed by what our senses and imagination cannot fully comprehend. Regardless of the sense of danger, the viewer simply cannot turn away, since mingled with the terrifying is something even more enthralling: "The mind feels itself moved in the representation of the Sublime in nature ... quickly alternating attraction towards, and repulsion from, the same Object."14

Like Kant, Burke focused on terror in the sublime and explored our attraction to it. In A Philosophical Enquiry into the Origin of Our Ideas of the Sublime and Beautiful, ${ }^{15}$ he described our fascination with frightening, at times dangerous events as arising from our natural feelings of self-preservation. He explains:

The passions which belong to self-preservation, turn on pain and danger; they are simply painful when their causes immediately affect us; they are delightful when we have an idea of pain and danger, without being actually in such circumstances. ... Whatever excites this delight, I call sublime. The passions belonging to self-preservation are the strongest of all the passions. ${ }^{16}$

Our instinctual feelings of self-preservation allow us to recognize situations that are potentially dangerous and to find delight in these moments. The delight arises when we realize we are not in immediate danger but in a position to watch with awe and respect. Today our fascination with this extreme sublime has permeated popular culture. No longer are these rare occurrences when the observer comes into actual contact with the natural sublime. The sublime is now enthralling people every day through video clips and whole television shows that focus on topics like violent storms, dangerous animals, or nature's extremes and oddities. The extreme sublime is everywhere and our students are watching.

While the extreme sublime begins as horror mingled with fascination, according to Kant it finishes with a humbling sense of knowing one's place in the world. For example, there is something both beguiling and frightening in the infinity of space that ultimately leaves the viewer with a sense of being definitively small. This is the sublime of Kant, the sublime that gives us a sense of our human 
worth: "When we are confronted with the overwhelmingly powerful, the weakness of our empirical selves makes us aware of our worth as moral beings."17 The extreme sublime serves to distance the observer from nature.

\section{The Connective Sublime}

The second type of sublime is found in the romantic poetry of Wordsworth and Coleridge, as well as the American transcendental philosophy of Emerson, Whitman, and Thoreau. These writers emphasize different aspects of the sublime than found in the extreme sublime of Kant and Burke, and I call this the connective sublime. In both forms, there is initially a sense of incomprehension and even fear, but while the distanced extreme sublime ends with humility, the connective sublime results in a connection between the self and nature. Rather than feeling insignificant in and separated from the world, with the connective sublime we are left with a feeling of connection to, and intimacy with, the world. The connective sublime highlights feelings of unity with nature along with a mixture of fear, fascination, and awe. The following lines by Ralph Waldo Emerson capture the feeling of the connective sublime as he describes a winter walk across Harvard Common:

Crossing a bare common, in snow puddles, at twilight, under a clouded sky, without having in my thoughts any occurrence of special good fortune, I have enjoyed a perfect exhilaration. Almost I fear to think how glad I am.... Standing on the bare ground,--my head bathed by the blithe air, and uplifted into infinite space,-all mean egotism vanishes.... I am nothing. I see all. The currents of the Universal Being circulate through me; I am part or particle of God. ${ }^{18}$

Emerson's experience is similar to the extreme sublime in some ways, but in other ways it differs greatly. Unlike Kant's sublime, Emerson is not left with a feeling of humbleness and modesty, but instead is elated by his connection with the universe. He has tapped into the energy coursing through nature and experiences "exhilaration." This universal current is an important idea for the transcendentalists, representing one's connection to the world. When Emerson writes that he "is nothing" it may sound Kantian, but he follows this line with "I see all" and moves into a description of being a "part or particle of God." While Kant writes that God's presence is also revealed in the sublime, he would likely not claim that the viewer becomes a part of God or nature through this experience. For Kant, the sublime occurs when we recognize some aspects of our separation from nature and autonomy rather than the unity expressed by Emerson.

Another important difference between Emerson's experience and that of the sublime described by Kant and Burke is that his experience happened with the ordinary. Kant saw the sublime in displays of great natural forces like hurricanes and tornados, writing, "The sublime is always great."1 In contrast, Emerson felt 
the sublime on an ordinary walk. Another example from Emerson illuminates both his feeling of connection to nature and his ability to find the sublime in the small and commonplace, as he describes his feelings upon gaining insight into the workings of an ant:

The instincts of the ant are very unimportant, considered as the ant's; but the moment a ray of relation is seen to extend from it to man, and the little drudge is seen to be a monitor, a little body with a mighty heart, than all its habits ... becomes sublime. ${ }^{20}$

It is unlikely that either Kant or Burke would have found the sublime in a mere ant, but here Emerson highlights several important parts of the connective sublime. The sublime exists in a connection to nature when "the ray of relation" is realized, when the onlooker sees how similar he is to an outwardly simple insect. For Emerson, the sublime represents a universal connection and happens the moment we realize this unity.

Along the same lines, in Art as Experience, Dewey wrote of the integration of the viewer and the object as an essential quality of aesthetic experiences:

For the uniquely distinguishing feature of esthetic experience is exactly the fact that no such distinction of self and object exists in it, since it is esthetic in the degree in which organism and environment cooperate to institute an experience in which the two are so fully integrated that each disappears. ${ }^{21}$

Similarly, Wordsworth, in his poem Lines Written a Few Miles Above Tintern Abbey, described this moment as:

A sense sublime

Of something far more deeply interfused

Whose dwelling is the light of setting suns

And the round ocean, and the living air,

And the blue sky, and in the mind of man,

A motion and a spirit, that impels

All thinking things, all objects of all thought,

And rolls through all things. ${ }^{22}$

Wordsworth described an idea common to many transcendental writers such that within everything is an underlying, unifying force, and to Emerson and Wordsworth, this force is sublime. Both writers devoted much of their effort to this feeling of union with nature, and the sublime represented the ultimate emotions of awe and unity.

\section{The SCIEnTific Sublime}

It is not only poets and philosophers who have written of the sublime; scientists have also described experiences that convey these same feelings. Maybe it 
is the sublime that attracts some people to the study of science and sustains their interest in the field. While the initial level of the sublime may first pique their interest, perhaps some are compelled to pursue scientific study as a result of deeper sublime understandings. This describes is another type of sublime, what I call the scientific sublime, that results from a combination of cognition and emotion. The scientific sublime may incorporate aspects of the extreme and connective sublime, but most importantly it represents feelings of awe and wonder that come only from a deep understanding. This sublime differs from that experienced by poets, philosophers, or casual observers in that it arises from knowledge of the phenomenon. This is in stark contrast to Kant who wrote that the sublime does not include cognition and instead things are judged sublime "merely by what strikes the eye."23

With the scientific sublime, feelings of awe and astonishment are based on understanding. It is only through a deep understanding of a phenomenon that one can appreciate its true complexity, and these understandings, when mixed with the emotion of reverence, are sublime.

\section{SCIENTISTS AND THE SUblime}

While the word "sublime" may not be used, the feelings behind the sublime are apparent in the writings of many scientists. For example, an emotional response brought on by scientific understanding is evident in Werner Heisenberg's writing about developing a new atomic physics:

At first I was deeply alarmed. I had the feeling that through the surface of atomic phenomena, I was looking at a strangely beautiful interior, and felt almost giddy at the thought that I now had to probe this wealth of mathematical structures nature had so generously spread out before me. ${ }^{24}$

Much of Heisenberg's description of physics echoes Kant and Burke's depiction of the extreme sublime. Heisenberg feels "deeply alarmed" and yet is "giddy" upon looking into the structures of atomic phenomena found in nature. Consistent with the extreme sublime, for Heisenberg there is something terrifying about peering into the inner workings of the universe. But it is also clear that these feelings came about only through his deep understanding of atomic physics. His brush with the sublime is not something that a casual observer could experience, instead only someone who understands atomic physics could be moved by its "beautiful interior."

The awe and wonder that arises from scientific knowledge is also evident in the following lines Heisenberg wrote to Einstein: "You must have felt this too: the almost frightening simplicity and wholeness of the relationships which nature suddenly spreads out before us and for which none of us was in the least prepared."25 Again, Heisenberg conveys feelings of the extreme sublime where he is in awe of the "frightening simplicity" of the relationships he has suddenly understood. This also highlights another important aspect of the scientific sublime-that through 
understanding one can see the interconnectedness of nature, or the "wholeness of the relationships." Notice, too, the emotions, a necessary ingredient in the scientific sublime. The passage to Einstein begins with "You must have felt this too"; Heisenberg uses "felt" rather than words like "seen," "discovered," or even "realized." In both of these passages the language is not the objective, neutral words that are ordinarily associated with scientists. Instead they are brimming with excitement and anticipation, embodying the sublime. His passages unmistakably show an emotional response to something great and powerful that comes about through scientific understanding

Another example of the scientific sublime can be found in the writing of Nobel Laureate physicist Richard Feynman. Where Heisenberg's writing showed an emotional response similar to that described by Burke and Kant, Feynman's writing more closely resembles the connective sublime of the romantic poets:

Poets say science takes away from the beauty of the stars-mere globs of gas atoms. Nothing is "mere." I too can see the stars on a desert night, and feel them. But do I see less or more? The vastness of the heavens stretches my imagination-stuck on this carousel my little eye can catch one-millionyear-old light ... ${ }^{26}$

In this passage, Feynman disagrees with those who argue that understanding the science behind a phenomenon reduces its aesthetic and romantic appeal, its sense of the sublime. He not only sees the stars for what they are scientifically, he feels their presence as well. Feynman's lines are reminiscent of those of Emerson describing his sense exhilaration occasioned by feelings of a strong connection to nature. The sublime is apparent in Feynman's emotional connection to the stars, his amazement at the "vastness of space," and in the understanding that he can glimpse "one-million-year-old light." Feynman makes it clear that his understandings of nature have not taken away from his enjoyment and appreciation of it, but instead have added to it. While poets can marvel at the stars' beauty, through a more analytical understanding of the stars, a scientist can also marvel at and be moved by their complexity. In these examples, it is apparent that scientists have a different understanding of the sublime than poets and philosophers. These scientists can feel the awe, admiration, and connection of the sublime when interacting with nature on an initial level, but they also experience these feelings as a result of a deeper understanding of nature.

\section{Scientific Sublime as Compelling Experiences}

The scientific sublime does not come from memorizing concepts, but arises from understanding ideas. Dewey referred to ideas as encompassing every part of an educative experience except those that are stagnant and fading. ${ }^{27}$ Ideas instigate action and lead to an experience as they are tested out either physically or in one's 
imagination. ${ }^{28}$ Dewey's aesthetic experiences differ from everyday experiences in that they are compelling events "fraught with suspense" through a history or plot that is full of emotion..$^{29}$ In a Deweyan aesthetic experience, the learner is driven forward by anticipation. This anticipation not only leads to a sense of drama or excitement, but is also a natural motivation for learning. Through anticipation "learners get a sense of what might be and are inspired to move forward. Thus, learning not only results in understanding, it is also compelled by it." ${ }^{30}$

This work draws on Dewey's explanations of aesthetic or educative experiences to understand experiences of the scientific sublime. Both are filled with emotion, and in both the learner is overwhelmed and engulfed by the experience: "The child is simply absorbed in what he is doing; the occupation in which he is engaged lays complete hold upon him." ${ }^{31}$ As a result of these experiences, the learner begins to see and be in the world differently--sublime and educative experiences transform the way we see the world. And while Dewey recognized that aesthetic experiences and their vital appreciations can apply to experiences with science, an exploration of the scientific sublime can shed light on teaching and learning in the sciences.

\section{Teaching to Foster the Scientific Sublime:}

\section{A Pedagogical Approach}

For this research, I created and taught a middle school science curriculum based on ideas drawn from Dewey's conception of aesthetic experiences and the sublime-extreme, connective, and most importantly, the scientific sublime. The curriculum consisted of two five-week units on the topics of weather and ecology. The goal was not only to increase student understanding, but also to foster feelings of the sublime. In creating the curriculum, I drew from previous work on aesthetics and science education ${ }^{32}$ and identified five aspects of teaching to foster experiences of the scientific sublime:

1. An emphasis on the content's big ideas

2. The use of metaphor

3. An emphasis on visualization

4. Highlighting the sublime

5. Modeling a sublime sensibility

\section{An Emphasis on the Content's Big IdeAs}

Often in science education, facts are overemphasized and the more important, unifying ideas are omitted. Prawat ${ }^{33}$ discussed the importance of focusing on essential ideas developed by content experts, with the assumption that some ideas are inherently more valuable than others. Identifying and emphasizing the essential ideas encourages the type of conceptual understanding necessary 
for scientific sublime experiences. Big ideas should not only explain the content, they should also be compelling in the Deweyan sense-inspiring possibilities to be explored. ${ }^{34}$ Rather than teaching a series of small, often disjointed concepts, when teaching with big ideas, the ideas drive the curriculum. For example, the weather unit's big idea was: "weather is the movement of energy." This idea is akin to the way meteorologists think of weather, but is not typically taught in school. The idea is powerful because it provides the necessary overview for understanding weather, what it is and why it exists. In contrast, the school's textbook did not mention weather as being driven by energy and instead built a weather unit on particulars, that is, various types of precipitation, pressure systems, and fronts. This typical reliance on specifics gives students understandings of what weather consists of, but not what weather is.

Big ideas should be more than just stagnant concepts to memorize; they should provide interesting, unifying understandings. They should also be broad enough to connect to other important ideas in science. When an idea succinctly explains a scientific process and when this idea is realized by the learner, it can provide a powerful, even sublime experience.

\section{The Use of Metaphor}

Like big ideas, metaphors can promote deep understanding by providing a lens through which students can make sense of the world. Cognitive scientists have long supported the use of metaphors as a way to connect concepts to objects in the physical world. ${ }^{35}$ Metaphors give students a way to grasp scientific complexity by engaging them more deeply in ideas. Dewey encouraged using metaphors and analogies that allow the learner to see patterns in nature and to see "familiar objects in a new light." ${ }^{36}$ Prawat discussed how metaphors, like plants as "food factories" or the heart as "pump," are a natural part of idea acquisition. ${ }^{37}$ In addition, scientists also utilize metaphors to aid creative thinking, understanding, and discovery. ${ }^{3}$

In science teaching, metaphors can highlight connections and patterns within and between phenomena that would be hard to imagine otherwise. A metaphor I used in the ecology unit to show primary succession was that we are in the midst of a "war" between man-made objects and nature. Through this metaphor, students saw the succession "war" happening all around them-a scraggly weed poking through a patch of asphalt or ivy climbing over and enveloping an old brick building. This metaphor was used to evoke feelings of the extreme sublime in students as they saw an epic battle between human beings and nature. Eventually, the details of the metaphor recede into the background and the scientific ideas are brought to the forefront. Also, as literary devices, metaphors stir the imagination and help foster experiences of the aesthetic or sublime. 


\section{An EMPHASis on Visualization}

It was not until my first few days of teaching about weather that I began to fully realize the power of pictures and video to evoke sublime experiences. As the unit progressed, it became clear just how moving a carefully chosen picture could be. Just as metaphors foster a creative way of thinking about science, so too can images. The science teacher can use photographs, video clips, or art to evoke feelings of the sublime. Some images instantly convey feelings of the sublime, while others need to be looked at more carefully and analyzed through scientific understandings for their deeper meanings to surface. For students to experience the scientific sublime they need to interact with the image in some way--through personal or social sense making. To foster these types of experiences, the teacher must model and scaffold the process of using ideas to create understandings and to help evoke feelings of astonishment or harmony. This can most readily be done through small group or whole-class discussion of what students, as well as teachers, see, feel, think, predict, or wonder about based on the imagery.

\section{Highlighting the Sublime}

This aspect of teaching includes calling attention to what is astonishing, terrifying, or unifying about the content. Aspects of the extreme sublime are often dramatic and easily pique student interest. However, the most important part of highlighting the sublime is what Pugh calls, "crafting the content," where "The teacher's task is to craft ordinary (and uninspiring) concepts into powerful ideas that have the potential to instigate action, transform perception, and expand value." ${ }^{39}$ Teachers must examine the content and create curriculum that either emphasizes the most potentially sublime ideas or emphasizes the sublime in otherwise regular ideastapping into what is also called "hot cognition." ${ }^{\text {"40 }}$ In the weather unit, this meant crafting the content around storms. The ecology unit focused largely on the interesting adaptations of plants and animals that enable them to thrive in their environments. Other ways of highlighting the sublime are to read first-hand accounts that emphasize experiencing the emotional impact of the content--for example reading stories of hurricane survivors, and sharing statistics that emphasize qualities like massive or minute size, power, extreme speed, and so on.

\section{Modeling a Sublime Sensibility}

To foster experiences of the scientific sublime, the teacher must model her own ways of being in the world-specifically, for being moved, appreciative, and inspired by aspects of the sublime in science. Pugh and Pugh and Girod ${ }^{41}$ used an apprenticeship model for this purpose and emphasized the creation of a classroom community of learners that values an artistic appreciation of scientific ideas. The teacher's task in 
creating this community is to model her own sublime sensibility and eagerness to be "swept-up" in the experience. To be truly captivated by the experience is what Wong calls the "the opposite of control" based on elements of Dewey's conception of educative experiences:

One must let go-as much as possible-one's long held ways of seeing, doing, understanding, and feeling. The degree that one undergoes, the degree that one can truly experience, is the degree that one can be open to the true nature of an outside influence. ${ }^{42}$

By releasing control and letting go of former ways of seeing, feeling, and understanding, we are truly open to a new experience and can undergo the effects of the sublime-be they expressing astonishment, horror, harmony, or unity. Through modeling this type of learning experience, a teacher can work to enculturate students in the scientific sublime. The teacher should create such a compelling vision of the content so that students are eager to become a part of it.

\section{Results and Discussion: Teaching for the Scientific Sublime}

This pedagogical approach was used to create and teach two 7th grade science units-one on weather (with approximately 50 students) and the other on ecology (with 24 students). Both units proved to be a success in terms of the resultant learning and in the positive experiences with science of the students. In both cases, students were given a pre and post multiple-choice test of questions typical of those found on the state's assessment exam as well as the classrooms' regular tests covering weather and ecology. Both groups of students showed a significant increase in learning.

Of course student learning was paramount in this experiment, but I was more intrigued by the experiences students reported as a result of this learning. In an attempt to gain an understanding of students' experiences, I gathered several types of qualitative data: audio recordings of class sessions; a teaching journal of my experiences; results of open-ended student surveys administered during and after the unit; and student interviews. The goals were not only to increase science knowledge, but also to initiate experiences of the sublime, most importantly, the scientific sublime, in the students.

Based on the collected data, it appears that the majority of students did indeed experience the sublime during their learning. Much of the language used in student writings and interviews resembled the language used by Kant and Burke to describe the sublime. The extreme and scientific sublime experiences were far more common than the connective. Student fascination with the extreme sublime and how this compelled them to move towards the deeper scientific sublime was a strong theme and may have interesting implications for future research. 


\section{Fascination with the ExtReme Sublime}

In both the weather and ecology units, students consistently showed interest in the extreme sublime. More than 200 years ago, Burke and Kant described a type of sublime that arose from fear of danger, terror, and obscurity resulting in a sense of "delightful horror." Be it a towering tornado or a cobra poised to strike, the extreme sublime astonished, moved, and ultimately delighted the students. They reported feelings of suspense along with Burke's "delightful horror" as they thought about storms and dangerous animals. The suspense is perhaps the ultimate of its kind since it deals with what Burke calls "self-preservation." It often created experiences that compelled students to look further into the phenomena and to begin to grapple with the underlying scientific ideas.

In the extreme sublime experiences of many of the students, the Deweyan sense of anticipation ${ }^{44}$ found in educative experiences seemed to be a part of the process. This anticipation is difficult to capture on a survey or in an interview, but it was often apparent in the classroom. When a new object or idea was introduced that related to the extreme sublime, I frequently noticed not only displays of awe and astonishment, but also urgency on behalf of the students to make sense of what they were seeing. Students were so moved by some objects or phenomena that they felt compelled to learn more about them. This is where the scientific sublime comes in - through the anticipation built by the extreme. Much of the time, students were equally awed with what they learned in light of the scientific ideas.

A good example from the ecology unit occurred when the concept of adaptation was introduced-characteristics that help animals survive in their particular environment. I began by showing pictures of extreme cases, the first of which was a walking-stick insect. The lights were dimmed and the picture was projected onto a large screen in the front of the room. I then asked students what they saw. By this point, they were accustomed to my methods and sat in the dark full of anticipation. The picture showed a nearly perfectly camouflaged walking-stick insect hidden among leaves on a branch. At first the students seemed puzzled and a bit disappointed, expecting to see something better than what appeared to be a normal branch. Within a few seconds, however, some began to see the insect and rushed to tell the rest of us what they saw. Instantly, the class was buzzing with reactions.

For some, this was yet another example of the potential danger found in nature. The fact that an insect, which many incorrectly assumed to be poisonous, could be so hidden was horrifying to these "city kids." I was completely surprised by this response; I never imagined the insect would induce such sublime feelings of horror. The sentiment of many was that nature was not only dangerous, but now deceptive; threatening animals could be hidden anywhere. Prompted by their fascination at the bizarre appearance of the animal, students immediately wanted to 
know why walking-stick insects look the way they do. At this point, we began our discussion of adaptation. In this example, the alarming aspects of the sublime created anticipation in the Deweyan sense and propelled students towards completion of the experience-scientific understandings.

\section{The Extreme Sublime and the Dangerous Aspects of Nature}

While the sublime described by Burke and Kant is typically a gripping and moving force for us all, the students often seemed to go to extremes themselves in the way they viewed nature as being dangerous. Nature as an ever-present potential danger became a particularly compelling idea to them. This was not surprising with the weather unit, since it was designed around storms. Admittedly, I capitalized on the enormous size, power, and destructive capabilities of these storms to pique student interest in learning the patterns and processes behind such events. The students were drawn-in by the extreme sublime, and I fed their fascination for the huge and horrific storms. I overtly highlighted the dangerous aspects of weather in hopes of fostering interest and appreciation for the energy and the processes involved. Conversely, I specifically set out to teach the ecology unit to highlight aspects of the connective sublime rather than the extreme sublime of the weather unit. I knew this would be a difficult task, since feelings of connection and unity are often less interesting than death and destruction, especially to 7 th graders.

I purposefully picked the topic of ecology in an attempt to teach the connective sublime, thinking the two were a natural fit. I planned to stress the connections between all living things and hoped to inspire Emerson or Thoreau-like experiences with nature. While I did stress these connections, my students were more intrigued by the biggest, fastest, and most dangerous in the animal world. Students were so enthralled by the extreme sublime that it became difficult for me to include aspects of the connective sublime in my teaching.

It was challenging, as a teacher, to foster the formation of little Emersons and Thoreaus when my students were more interested in the Crocodile Hunter. Yet as anyone who has ever watched the Crocodile Hunter knows, he exuded feelings of awe, astonishment, and admiration for these dangerous animals. I quickly came to the conclusion, right or wrong, that if I was to promote experiences of the scientific sublime, I was going to have to do so via the extreme sublime. The perilous aspects of the extreme appealed to my students far more than anything else. This was obvious when I asked "Misty," an ecology student, what parts in the unit most impressed her. She appeared to think about her answer and then replied, "Well, I really like the tapeworms and the poisonous salamanders."

Besides the Kantian sense of delight we get from the extreme sublime, there may be other reasons why the ecology students were drawn to the dangerous aspects of nature. Few of these students had much experience with animals or 
nature, and what experiences they had were largely negative. On the second day of teaching, I asked "Jackie" if he spent much time outside in nature and received a quizzical look, as he explained, "I'm more of an inside kind of guy." This was a typical sentiment. These students were "city kids"; they attended a large urban school and were not in close proximity to the forests, fields, and wetlands that served as the backdrop of the stories I told. As an illustration of this issue, I am reminded of a time when the class discussed animals with warning colors. I mentioned that while lethal animals, like the poison arrow tree frog, had bright markings to warn potential predators, so too do animals more common to us, like the skunk. I asked the class where they would be likely to find skunks, expecting to hear something along the lines of woods or meadows, but instead Jackie replied, "in the projects." Perhaps because the students had few positive experiences with nature and were more familiar with its dangerous aspects, they were more drawn to the extreme sublime and relatively resistant to the connective sublime.

In the first week of class, the role of decomposers in the circle of life was discussed, and I brought in examples of tree fungus, mushrooms, and mold that I found on in the woods. The majority of students made it clear that they had never seen such things before; they were not about to touch them, and they could not believe I had nothing better to do than look for such things. There was only moderate interest in the objects until one student mentioned that he heard mushrooms were poisonous, at which point they all gathered around to get a better look. When it came to animals, some of the students had dogs or cats, but they often had sad or scary stories to tell about these animals. Many of the dogs students knew were "tough" dogs who were not so much pets as they were potential sources of danger. Several students had violent dog stories, like Allison, who explained that, "Dogs are good predators 'cause when my dogs killed my cat, they broke his back legs."

The other common experience my ecology students had with animals was what they saw on nature television shows. In interviews when I asked students if they had begun to look at animals differently as a result of what they were learning in class, only a few students mentioned animals they had actually seen. Many more talked about TV shows they were watching, and were now more likely to watch, and how the actions of animals were making more sense to them now. I added to this common collection of experiences by showing a nature movie titled Super Predator early on in the unit. An informative yet graphic film, it seemed to have made more of an impact on them than anything else we did during the five weeks.

Given that many of the experiences students had with animals involved some type of violence, it is not surprising that they were drawn to aspects of the extreme sublime in ecology. Animals and many plants were seen as something to be afraid of, and students were eager to study them. They saw science as a way to better understand the risky natural world-knowledge that could help keep them safe. 


\section{The Extreme Sublime and a Fear of Nature}

The ecology students clearly saw the natural world as a dangerous place. While many of them came to the unit with some fear of nature, I have to wonder how much of this trepidation the teaching instilled in them. I did not intend to make them afraid of nature, in fact I was hoping for the opposite. I have an intense feeling of connection to nature, and I had hoped to model these feelings of harmony and awe for my students. In this regard, I was clearly ineffective. The students were not interested and instead asked for aspects of the extreme sublime-the dangerous, the massive, the overpowering. I remember a pivotal point in my teaching when the extreme sublime crept in and took over.

On this day we were discussing the important prey animal adaptation of camouflage, and I was hoping to expose students to the wondrous abilities of animals in our part of the world to blend into their surroundings. I showed a picture of a grassy meadow where three very alert white-tailed deer stood like statues, almost dissolving into their surroundings. The students were hardly impressed. Out of courtesy to me, they looked over the picture and agreed that the deer had good camouflage. But they knew enough about prey animals now to know that these deer were trying to hide from something and they wanted to know what that was. I explained that in our area humans were really the only predators these deer had. As I said this, I saw some students lose interest. I wanted so badly for them to be engaged and even entertained that I abandoned my hopes of the connective sublime and added, "but maybe the deer saw a coyote."

The mention of a coyote instantly aroused their interest. Some students actually sat up straighter in their seats and leaned in towards the screen to take another look. Excited by their interest, I began to talk about coyotes. I explained that they had recently made a comeback in the area and that there had even been reports of them killing farm animals on nearby university land. Although I explained that coyotes were too small and skittish to be a threat to anything bigger than a rabbit or lamb, students were fascinated with the idea of a predator roaming the area. This was an influential experience that changed the way many of the students saw the world, as was evident from the several student-reported coyote "sightings" I heard about in the following weeks. For me, this was also an important moment; it was when I too easily gave up my quest for conveying the connective sublime.

To return to the issue as to whether or not I intensified students' pre-existing fears of nature, I have to conclude that in many ways I did. I have described what happened in the ecology unit in terms of giving up on the connective sublime and giving students what they wanted-danger. In the weather unit, I highlighted the most dangerous parts of "the movement of energy"-violent storms. In response to a survey question that asked if students looked at weather differently as a result of the weather unit, "John" wrote, "Yes, I think weather is a lot more dangerous 
now." However, he also wrote that he liked learning about storms, hurricanes in particular, and that storms were "cool."

Many teachers know what Kant and Burke so laboriously described: students are fascinated with the dangerous aspects of science. The interesting question then becomes, is it wrong to explicitly teach to the extreme sublime in order to reach the understanding and affect of the scientific sublime? Should science teachers use their students' fascination with the terrifying and awe-inspiring to act as a motivator for content learning?

This is obviously a complex issue and one that I have mixed feelings about. Looking back on the experiences of my students, I find some justification in teaching towards the extreme sublime. In both classes, students were more often than not engaged and excited about learning science. I was able to use their fascination with the extreme sublime to teach scientific processes and ideas that enabled them to make sense not only of nature's extremes, like tornadoes and lions, but also of the more common and everyday, like a cloudy sky or a pet dog. These are all positive and difficult to attain, so I certainly see some merit in the approach. But is engaged, active learning worth encouraging a fear of nature? Ultimately, my answer to this question is "yes," for the following reasons.

If respect and appreciation for nature is a goal in science education, then teaching to foster the extreme sublime is an effective way of instilling these feelings. The feelings of appreciation for nature may initially arise out of fear and fascination with this fear, but through increased understanding, the fear becomes something different. Rather than an ignorant fear, a positive first step for students may be a fear based on knowledge-what might be called a "healthy fear." The ecology students began the unit afraid of lions simply based on the big cats' alleged ferocity. As we progressed through the unit, students were still rightly afraid of lions, but this fear was now based on an understanding of the animals' incredible physical prowess and behavioral traits that make them "super predators." Once students have some understanding of what makes the animal terrifying, some of the terror begins to subside. To return to Burke, he described a type of sublime as "obscurity." Of this topic he wrote, "To make anything very terrible, obscurity seems in general to be necessary. When we know the full extent of danger, when we can accustom our eyes to it, a great deal of the apprehension vanishes. ${ }^{\text {"45 }}$ I like to think that by teaching to the extreme sublime, I not only worked to engage and motivate students, I also helped to accustom their eyes to their fears.

\section{BiBLIOGRAPHY}

Abelson, Robert. "Computer Simulation of "Hot Cognition." In Computer Simulation and Personality: Frontier of Psychological Theory, edited by Silvan Tomkins and Samuel Messick, 277-98. New York: Wiley, 1963. 
Brown, John Seely, Allan Collins, and Paul Duguid. "Situated Cognition and the Culture of Learning." Educational Researcher 18, no. 1 (1989): 32-42.

Burke, Edmund. A Philosophical Enquiry into the Origin of Our Ideas of the Sublime and Beautiful. Edited by J. T. Boulton. Oxford: Basil Blackwell, 1987 (Original work published 1757).

Chandrasekhar, Subrahmanyan. Truth and Beauty: Aesthetic Motivations in Science. Chicago: University of Chicago Press, 1990.

Collins, Allan, John Seely Brown, and Susan Newman. "Cognitive Apprenticeship: Teaching Students the Craft of Reading, Writing, and Mathematics." In Knowing, Learning, and Instruction: Essays in Honor of Robert Glaser, edited by Lauren Resnick, 453-94. Hillsdale, NJ: Erlbaum, 1989.

Dawkins, Richard. Unweaving the Rainbow: Science, Delusion and the Appetite for Wonder. New York: Mariner Books, 1998.

Dewey, John. The School and Society. Chicago: University of Chicago Press, 1990.

_-_. Experience and Nature. Chicago: University of Chicago Press, 1929.

- _ - "How We Think: A Restatement of the Relation of Reflective Thinking to the Educative Process." In John Dewey: The Later Works, 1925-1953, Vol. 8, edited by Jo Ann Boydston. Carbondale: Southern Illinois University Press, 1988.

-_- Art as Experience. New York: Perigee Books, 1980.

Dirac, Paul. "Why We Believe in the Einstein Theory." In Symmetries in Science, edited by Bruno Gruber and Richard Millman, 1-11. New York: Plenum Press, 1980.

Emerson, Ralph Waldo. "Nature.” In The Essential Writings of Ralph Waldo Emerson, edited by Brooks Atkinson, 3-42. New York: The Modern Library, 2000 (Original work published 1836).

Greeno, James, Allan Collins, and Lauren Resnick. "Cognition and Learning." In Handbook of Educational Psychology, edited by David Berliner and Robert Calfee, 15-46. New York: Macmillan, 1996.

Girod, Mark. Teaching 5th Grade Science for Aesthetic Understanding. Unpublished doctoral dissertation, Michigan State University, East Lansing, 2001.

- _ - and E. David Wong. "An Aesthetic (Deweyan) Perspective on Science Learning: Case Studies of Three Fourth Graders." The Elementary School Journal 102, no. 3 (2002): 199-224.

- - C Cheryl Rau, and Adele Schepige. "Appreciating the Beauty of Science Ideas: Teaching for Aesthetic Understanding." Science Education 87, no. 4 (2003): 547-87.

Jackson, Philip. John Dewey and the Lessons of Art. New Haven, MA: Yale University Press, 1998.

Kant, Immanuel. Observations on the Feeling of the Beautiful and Sublime. Translated by J. T. Goldthwait. Berkeley: University of California Press, 1960 (Original work published 1764). 


\section{Shane Cavanaugh}

-_- Critique of Judgment. Translated by J. C. Meredith. Oxford, UK: Oxford University Press, 1952 (Original work published 1790).

Lakoff, George, and Mark Johnson. Metaphors We Live By. Chicago: University of Chicago Press, 1980.

Lave, Jean, and Etiene Wenger. Situated Learning: Legitimate Peripheral Participation. New York: Cambridge University Press, 1991.

McAllister, James. Beauty and Revolution in Science. New York: Cornell University Press, 1999.

Miller, Arthur. Insights of Genius: Imagery and Creativity in Science and Art. Cambridge, MA: MIT Press, 2000.

National Research Council. National Science Education Standards. Washington, DC: National Academy Press, 1996.

Ortony, Andrew. Metaphor and Thought. London: Cambridge University Press, 1979. Palincsar, Annemarie Sullivan, and Ann Brown. "Reciprocal Teaching of Comprehension-Fostering and Comprehension-Monitoring Activities." Cognition and Instruction 1, no. 2 (1984): 117-75.

Poincare, Henri. The Foundations of Science. Translated by George Bruce Halsted. Lancaster, PA: Science Press, 1946.

Prawat, Richard. "The Value of Ideas: The Immersion Approach to the Development of Thinking." Educational Researcher 20, no. 2 (1991): 3-10.

_-_. "The Value of Ideas: Problems Versus Possibilities in Learning." Educational Researcher 22, no. 6 (1993): 5-16.

-_- "Dewey, Peirce, and the Learning Paradox." American Educational Research Journal 36, no.1 (1999): 47-76.

Pugh, Kevin. Idea-Based, Transformative Experiences in Science: What Are They and How Do You Foster Them?” Unpublished doctoral dissertation, Michigan State University, East Lansing, 2000.

- _- "Teaching for Transformative Experiences in Science: An Investigation of the Effectiveness of Two Instructional Elements." Teachers College Record 104 (2002): 1101-37.

-_- "Newton's Laws Beyond the Classroom Walls." Science Education 88, no. 2 (2004): 182-96.

- _ - and Mark Girod. "Science, Art, and Experience: Constructing a Science Pedagogy from Dewey's Aesthetics." Journal of Science Teacher Education 18, no. 1 (2006): 9-27.

Root-Bernstein, Robert, and Michele Root-Bernstein. Honey, Mud, Maggots, and Other Medical Marvels. Boston, MA: Houghton Mifflin, 1997.

_-_, and Michele Root-Bernstein. Sparks of Genius. Boston, MA: Houghton Mifflin, 1999.

Sykes, Christopher. No Ordinary Genius: The Illustrated Richard Feynman. New York: W. W. Norton, 1996. 
Tauber, Alfred. The Elusive Synthesis: Aesthetics and Science. Boston: Kluwer Academic Publishers, 1997.

Wechsler, Judith. On Aesthetics in Science. Cambridge: The MIT Press, 1978.

Wong, E. David. "Beyond Control and Rationality: Dewey, Aesthetics, Motivation, and Educative Experiences." Teachers College Record 109, no. 1 (2007): 192-220.

_-_, Becky Packard, Mark Girod, and Kevin Pugh. "The Opposite of Control: A Deweyan Perspective on Intrinsic Motivation in 'After 3' Technology Programs." Journal of Computers in Human Behavior 16 (2000): 313-38.

_- - Kevin Pugh, and The Deweyan Ideas Group at Michigan State University. "Learning Science: A Deweyan Perspective." The Journal of Research in Science Teaching 38 (2001): 317-36.

Wordsworth, William. "Lines Written a Few Miles Above Tintern Abbey." In Oxford Authors: William Wordsworth. Edited by Stephan Gill. Oxford, England: Oxford University Press, 1990.

\section{NOTES}

1. An earlier version of this paper was presented at the Annual Meeting of the American Educational Research Association, Montreal, Canada, April 2005.

2. National Research Council, National Science Education Standards (Washington, DC: National Academy Press, 1996).

3. Subrahmanyan Chandrasekhar, Truth and Beauty: Aesthetic Motivations in Science (Chicago: University of Chicago Press, 1990); Richard Dawkins, Unweaving the Rainbow: Science, Delusion and the Appetite for Wonder (New York: Mariner Books, 1998); Paul Dirac, "Why We Believe in the Einstein Theory," in Symmetries in Science, ed. Bruno Gruber and Richard Millman (New York: Plenum Press, 1980); James McAllister, Beauty and Revolution in Science (New York: Cornell University Press, 1999); Henri Poincare, The Foundations of Science, trans. George Bruce Halsted (Lancaster, PA: Science Press, 1946); Robert RootBernstein and Michele Root-Bernstein, Honey, Mud, Maggots, and Other Medical Marvels (Boston, MA: Houghton Mifflin, 1997); Robert Root-Bernstein and Michele Root-Bernstein, Sparks of Genius (Boston, MA: Houghton Mifflin, 1999); Alfred Tauber, The Elusive Synthesis: Aesthetics and Science (Boston: Kluwer Academic Publishers, 1997); and Judith Wechsler, On Aesthetics in Science (Cambridge: The MIT Press, 1978).

4. Mark Girod, Teaching 5th Grade Science for Aesthetic Understanding (Unpublished doctoral dissertation, Michigan State University, East Lansing, 2001); Mark Girod and E. David Wong, "An Aesthetic (Deweyan) Perspective on Science Learning: Case Studies of Three Fourth Graders," The Elementary School Journal 102, no. 3 (2002): 199-24; Mark Girod, Cheryl Rau, and Adele Schepige, "Appreciating the Beauty of Science Ideas: Teaching for Aesthetic Understanding," Science Education 87, no. 4 (2003): 547-87; Kevin Pugh, Idea-Based, Transformative Experiences in Science: What Are They and How Do You Foster Them? (Unpublished doctoral dissertation, Michigan State University, East Lansing, 2000); Kevin Pugh, "Teaching for Transformative Experiences in Science: An Investigation of the Effectiveness of Two Instructional Elements," Teachers College Record 104 (2002): 1101-37; Kevin Pugh, "Newton's Laws Beyond the Classroom Walls," Science Education 88, no. 2 (2004): 182-96; Kevin Pugh and Mark Girod, "Science, Art, and Experience: Constructing 
a Science Pedagogy from Dewey's Aesthetics," Journal of Science Teacher Education 18, no. 1 (2006): 9-27; E. David Wong, "Beyond Control and Rationality: Dewey, Aesthetics, Motivation, and Educative Experiences," Teachers College Record 109, no. 1 (2007): 192-220; E. David Wong et al., "The Opposite of Control: A Deweyan Perspective on Intrinsic Motivation in 'After 3' Technology Programs," Journal of Computers in Human Behavior 16 (2000): 313-38; E. David Wong, Kevin Pugh and The Deweyan Ideas Group at Michigan State University, "Learning Science: A Deweyan Perspective," The Journal of Research in Science Teaching 38 (2001): 317-36.

5. Root-Bernstein and Root-Bernstein, Honey, Mud, Maggots, and Other Medical Marvels, 25.

6. Edmund Burke, A Philosophical Enquiry into the Origin of Our Ideas of the Sublime and Beautiful, ed. by J.T. Boulton (Oxford: Basil Blackwell, 1987), 51.

7. Ibid.

8. Immanuel Kant, Observations on the Feeling of the Beautiful and Sublime, trans. J. T. Goldthwait, (Berkeley, CA: University of California Press, 1960); Immanuel Kant, Critique of Judgment, trans. J.C. Meredith (Oxford, UK: Oxford University Press, 1952).

9. Kant, Observations on the Feelings of the Beautiful and Sublime, 27.

10. Ibid, 131.

11. Ibid.

12. Kant, Critique of Judgment.

13. Kant, Observations on the Feelings of the Beautiful and Sublime, 26.

14. Kant, Critique of Judgment, 120.

15. Burke, A Philosophical Enquiry into the Origin of Our Ideas of the Sublime and Beautiful.

16. Ibid, 51.

17. Kant, Critique of Judgment, 131.

18. Ralph Waldo Emerson, "Nature," in The Essential Writings of Ralph Waldo Emerson, ed. Brooks Atkinson (New York: The Modern Library, 2000), 6.

19. Kant, Observations on the Feelings of the Beautiful and Sublime, 131.

20. Emerson, 15.

21. John Dewey, Art as Experience (New York: Perigee Books, 1980), 249.

22. William Wordsworth, "Lines Written a Few Miles Above Tintern Abbey," in Oxford Authors: William Wordsworth, ed. Stephan Gill (Oxford, England: Oxford University Press, 1990), 134.

23. Kant, Critique of Judgment, 138.

24. Arthur Miller, Insights of Genius: Imagery and Creativity in Science and Art (Cambridge, MA: MIT Press, 2000), 383.

25. Chandrasekhar, Truth and Beauty: Aesthetic Motivations in Science, 53.

26. Christopher Sykes, No Ordinary Genius: The Illustrated Richard Feynman, (New York: W. W. Norton, 1996), 17.

27. John Dewey, Experience and Nature (Chicago: University of Chicago Press, 1929).

28. Wong et al., "Learning Science: A Deweyan Perspective."

29. Dewey, Art as Experience, 43.

30. Girod and Wong, "An Aesthetic (Deweyan) Perspective on Science Learning: Case Studies of Three Fourth Graders," 204.

31. John Dewey, The School and Society, (Chicago: University of Chicago Press, 1990), 145. 
32. Girod, Teaching 5th Grade Science for Aesthetic Understanding; Girod and E. David Wong, "An Aesthetic (Deweyan) Perspective on Science Learning: Case Studies of Three Fourth Graders"; Girod, Rau, and Schepige, "Appreciating the Beauty of Science Ideas: Teaching for Aesthetic Understanding"; Pugh, Idea-Based, Transformative Experiences in Science: What Are They and How Do You Foster Them?"; Pugh, “Teaching for Transformative Experiences in Science: An Investigation of the Effectiveness of Two Instructional Elements"; Pugh, "Newton's Laws Beyond the Classroom Walls"; Pugh and Girod, "Science, Art, and Experience: Constructing a Science Pedagogy from Dewey's Aesthetics"; Wong, "Beyond Control and Rationality: Dewey, Aesthetics, Motivation, and Educative Experiences”; E. David Wong et al., "The Opposite of Control: A Deweyan Perspective on Intrinsic Motivation in "After 3" Technology Programs"; Wong, Pugh and The Deweyan Ideas Group at Michigan State University, "Learning Science: A Deweyan Perspective".

33. Richard Prawat, "The Value of Ideas: The Immersion Approach to the Development of Thinking," Educational Researcher 20, no. 2 (1991): 3-10; Richard Prawat, “The Value of Ideas: Problems Versus Possibilities in Learning," Educational Researcher 22, no. 6 (1993): 5-16; Richard Prawat, "Dewey, Peirce, and the Learning Paradox," American Educational Research Journal 36, no.1 (1999): 47-76.

34. Prawat, "The Value of Ideas: Problems Versus Possibilities in Learning."

35. George Lakoff and Mark Johnson, Metaphors We Live By (Chicago: University of Chicago Press, 1980); Andrew Ortney, Metaphor and Thought (London: Cambridge University Press, 1979).

36. John Dewey, "How We Think: A Restatement of the Relation of Reflective Thinking to the Educative Process," in John Dewey: The Later Works, 1925-1953, Vol. 8, edited by Jo Ann Boydston (Carbondale: Southern University Press, 1988), 278.

37. Prawat, "Dewey, Peirce, and the Learning Paradox."

38. Root-Bernstein and Root-Bernstein, Sparks of Genius.

39. Pugh, Idea-Based, Transformative Experiences in Science: What Are They and How Do You Foster Them?, 61.

40. Robert Abelson, "Computer Simulation of "Hot Cognition", in Computer Simulation and Personality: Frontier of Psychological Theory, ed. Silvan Tomkins and Samuel Messick (New York: Wiley, 1963), 277-98.

41. Pugh, Idea-Based, Transformative Experiences in Science: What Are They and How Do You Foster Them?; Pugh and Girod, "Science, Art, and Experience: Constructing a Science Pedagogy from Dewey's Aesthetics."

42. Wong, "Beyond Control and Rationality: Dewey, Aesthetics, Motivation, and Educative Experiences," 321.

43. Burke, A Philosophical Enquiry into the Origin of Our Ideas of the Sublime and Beautiful, 73.

44. Dewey, "How We Think: A Restatement of the Relation of Reflective Thinking to the Educative Process."

45. Burke, A Philosophical Enquiry into the Origin of Our Ideas of the Sublime and Beautiful, 58.

Shane Cavanaugh is at Central Michigan University.

Email: cavan1s@cmich.edu 
